\title{
Disarmament and Development: An Idea Whose Time Should Have Come
}

\author{
Inga Thorsson
}

In the first part of this article I shall reflect on some of the reasons that have been advanced for the lack of progress on disarmament and development. My arguments are based on my position as chairman from 1978 to 1981 of the United Nations Group of Governmental Experts on the Relationship between Disarmament and Development - whose members came from 27 countries, from the West and from the East, from the industrial North as well as from the developing South, and on experience I have gained since then by continuously examining this crucial issue. In the second part I shall try to develop some ideas about how to put the disarmament-development relationship back on the international agenda.

However, before I discuss the reasons why, as the task given to me seems to indicate, something went wrong, let me recall the mandate given to, and the main conclusions arrived at, by the UN Group. In accordance with the mandate of the General Assembly our three main tasks were as follows:

(i) to assess present day utilisation of human and material resources for military purposes;

(ii) to analyse the economic and social effects of the arms race on such elements of the economy, at national and international levels, as economic growth and productivity, employment and inflation, international trade and international monetary systems;

(iii) to look into foreseeable short and long term problems that might appear when, in a disarmament situation, resources could be converted from military to constructive civilian purposes.

I should also like to emphasise that the General Assembly asked us to make the study forward-looking and policy-oriented, with particular emphasis on the possibilities of making a contribution to the establishment of a New International Economic Order.
The Group arrived at three main conclusions:

(i) The world finds itself at a crossroads. It can either continue to pursue the arms race or it can move towards a more sustainable economic and political order. It cannot do both, because the arms race and development compete for the same resources;

(ii) Irrespective of economic systems and levels of economic development, all countries would benefit economically from an effective disarmament process. They would thus have a mutual enlightened self-interest in disarmament;

(iii) In a disarmament situation, governments would face certain conversion problems. If solutions to these problems were well planned and prepared, they would cause no serious technical and economic difficulties.

In approving the Group's report, including its recommendations, the General Assembly in 1982 advised Governments of Member States:

(i) to reconsider their present policies of secrecy concerning the real costs, economic, social and human, inherent in military resource use;

(ii) to start to plan and prepare for a conversion process which could be implemented in a disarmament situation.

At this stage I must state that, like so many other economists world-wide, I believe firmly that the economic factor - at least over the longer run - quite decisively works for disarmament. In my view, the reason why this argument has not come more forcibly to the fore is the extraordinarily short-sighted and unimaginative policies of the political leaders of the major powers, who appear to believe that the task entrusted to them by their voters is to promote peace through military strength - indeed, if possible through military superiority. These are dangerously outdated concepts of national security, in the 40th year of the nuclear age and in an increasingly interdependent world.

IDS Bulletin. 1985, vol 16 no 4, Institute of Development Studies. Sussex 
Thus, I do not believe that the failure so far of the political leaders of the dominant powers to recognise that an intensified arms race will ultimately bring economic ruin, is due to gaps or inconsistencies in the UN study or for that matter in the Brandt and Palme reports. The facts are there, in the case of the UN study collected through a research programme involving more than 100 economists around the world. The analyses are there, as well as the conclusions and the recommendations. The time is ripe for decisions and action

But to make the required decisions and actions would of course require rather drastic changes in the behaviour of political leaders everywhere, and particularly those of the dominant military powers. The UN Governmental Expert Group was aware of this. But it was also painfully aware that it was not within its mandate, nor within its competence to suggest the necessary means by which these decisions could be reached. To achieve this, to create a political constituency for disarmament, would require a political process at the national level, something to which a Governmental Group within the UN unfortunately cannot directly contribute.

But there are other reasons why the international system can to some extent be blamed for the present deadlock. In my views there is not enough understanding of the interlinkages between the numerous global crises of our times, including the arms race. To isolate this particular global problem from the world economic crisis with all its components - the resource scarcities, the polarisation of wealth and poverty within and among nations, to mention but two of the global problems of our age - is to disregard some of the fundamental reasons for the social and political unrest now liable to emerge at both national and international levels, with increasingly dangerous repercussions

This becomes painfully evident when one looks at the way in which countries in the so-called Third World have been affected by the arms race and the international trade in weapons. First, there is the need to recall the well known fact that almost all of the numerous armed conflicts in the world since 1945 have occurred in the Third World [United Nations 1983]. One of the many reasons for this tragic situation seems to be the links between the East-West conflict and the almost complete lack of progress in the North-South dialogue. These links have several dimensions. Here, in my view, are some of them:

Political: Though being so absorbed by the East-West conflict, the major powers fail to react to polarisation between rich countries in the industrial North and poor countries in the developing South.
Economic: By continuing and intensifying the arms race, the parties to the East-West conflict worsen the world-wide economic cris is, the costs of which tend to be imposed on the South much more than on the North.

Military: The parties to the East-West conflict, especially the superpowers, make it more difficult to solve conflicts between countries in the South, by tying developing countries, or groups of developing countries, to their respective military blocs in order to serve their own purposes and to strengthen their own power positions.

As I see it, the superpowers in their arrogance conduct their policies with respect to the small and medium powers of the world only in relation to the significance of these nations to their own mutual and conflictridden relationship. They are able to behave in this manner because of their present economic, technical, military and, thus, political dominance, which also enables them to ignore the United Nations, when they find it expedient.

No wonder then, that the superpowers, but also major military powers, consider themselves entitled to intervene more or less openly in conflicts in the Third World. A Hungarian researcher, Istvan Kende, has estimated that out of 120 armed conflicts between 1945 and 1975, in 70 - well over half - there was outside intervention from the North [Kende 1980]. In no year since 1945 have there been less than four major armed conflicts in progress in the Third World. The same interventionist approach is reflected in the flow of arms from the industrialised to the developing world, entailing rapidly increasing militarisation, as well as the maintenance of a global net work of military facilities and bases, with over $1.8 \mathrm{~m}$ soldiers currently stationed on foreign territory, including that of around 70 developing countries.

Arms deliveries to developing countries (according to the figures of the US Arms Control and Disarmament Agency) have increased from $\$ 14.4$ bn in constant 1981 dollars in 1972 to $\$ 28.2$ bn in 1982 . Agreements rose even more steeply, from $\$ 10.5$ bn in 1973 to $\$ 46.2$ bn in 1980 . Indust rialised countries in the North have been only too eager to play the supplier. Indeed, during the world economic crisis the arms industries in the North have been among the few sectors that have continued to flourish. In 1984, according to a report released by the US Census Bureau in April 1985, 10 of the largest arms industries realised on average a 25 per cent return on equity compared to an average return of 12.8 per cent for other manufacturers.

What, then, are the economic effects of arms imports on the economies of the South? A number of the 
40-odd research reports submitted to the UN for our study on the relationship between disarmament and development show that increased military spending tends to be related to lower investment, to greater tax burdens, to cuts in consumption and social welfare spending and to inflation. In recent years another factor has come into prominence: the addition to the debt burden. In a study that I recently undertook for the Swedish Government, it was found that arms imports are responsible for around 25 per cent of the debt burden of countries in the South. Another estimate, reported in the UN 1985 Report on the World Social Situation, indicates that in at least 4 of the 20 countries with the largest foreign debt in 1983 , the value of arms imports amounted to 39 to 40 per cent or more of the rise in debt between 1976 and 1980 [UN 1985].

The negative effects in social and human terms are also considerable. In a report to the UN Group, the American economists Bruce Russett and David Sylvan estimated various social opportunity costs of arms purchases, examining their potential relationship to health and literacy. They found that for an average developing country, with a population of $8.5 \mathrm{mn}$ and a GNP per capita of around $\$ 350$ (at 1970 prices), the first $\$ 200 \mathrm{mn}$ of arms imports would add approximately 20 additional infant deaths per 1,000 live births, decrease average life expectancy by three to four years, and result in 13 to 14 fewer literate adults out of every 100.

It can be reasonably assumed that such a deterioration of conditions of human life would also result in increased social tensions and political unrest. And in the unfortunately numerous developing countries ruled by military or authoritarian regimes, this could well be another reason for the use of military force to keep internal tensions and unrest under control.

However, in the 1980 s there has occurred a rather remarkable shift in the pattern of the international arms trade, most markedly in terms of the total volume of sales. According to a recent US Congressional Research Service report [Grimmet 1984] both arms transfers and arms deliveries have been substantially reduced. Agreements plunged from a record high of $\$ 46.8$ bn in 1982 to $\$ 24.7$ bn in 1983 , a drop of 47 per cent. In its 1985 Yearbook, the Stockholm International Peace Research Institute (SIPRI) notes a similar decline in arms deliveries. This decline follows directly from the world-wide economic crisis and the closely related debt problems faced by so many count ries in the Third World. The fact is that the hard currency earnings needed to purchase arms are no longer there and, because of the international debt crisis, credits to buy them are not available either.
Some might think I have dealt unduly with the military situation in countries in the South. However, I happen to believe that the latter not only cause serious political, economic, social and human problems in Third World countries themselves, but could be decisive for the fut ure of the rest of the world. In spite of the terrifying arms race between the superpowers, the disarmament-development debate takes on ominous proportions when looked at from a Third World perspective.

I now turn to the second part of this article: how and in what form could disarmament and development be put back on the international agenda?

First, I should say that in the UN context the issue is alive and well. By a decision at the 37 th session of the Assembly in 1982 - when the UN report, including its conclusions and recommendations, was approved it will be placed on the agenda 'at regular intervals' beginning with the 40th session in Autumn. This implies that governments of Member States will be continously reminded of its existence, whatever that is worth. Furthermore, the General Assembly has decided to convene a special UN Conference on Disarmament and Development, in early Autumn 1986. My own experience is that this has stimulated favourable reactions around the world, not least among influential groups of international nongovernmental organisations.

But, what happens in the real world? The Brandt, Palme and Thorsson reports have not yet stirred the international political community because - as already stated - of the myopic and outdated security concepts of today's dominant political leaders, leading them to neglect the extent of the mutual enlightened self-interest among nations in an increasingly interdependent world. Unfortunately, other pressures will continue to impose themselves on political events. Above all, the arms race has become a major factor in the world economic crisis, influencing economies all over the world. The sharp decline in Third World arms purchases is an early warning. Purchases may not remain at their present low level, but specialists in the international arms trade seem to believe that they will never again reach the peak of 1982 .

However, the economic effects of the arms race are not confined to the countries of the South. The USSR is not the only major power which will be forced to discover the need for its own disarmamentdevelopment strategy. Whatever President Reagan said in the 1984 election campaign and whatever the indications of economic recovery in the United States, it is likely that the difficulties apparent in US civilian industry will remain, and that the competitiveness of American products will continue to decline unless US 
military expenditures are brought to a standstill or reduced. No trade war with Japan or Europe will rescue an economy whose GNP growth has mainly depended on an absurd military build-up, and which devotes between $35-40$ per cent of its total R \& D to military purposes, denying civil industries the resources badly needed for innovation and modernisation. The continued effects of soaring military expenditures and budget, trade and (for the first time this century) balance of payments deficits are said to have made the richest economy in the world a net debtor to the outside world to the tune of about $\$ 100$ bn.

It is generally acknowledged that the only really safe basis for national security is a strong and sound economy. The time will come, perhaps in the late 1980 s or early 1990s, when not only the US but also other major military powers will be compelled by economic circumstances to change their present course, to reduce their military spending and to convert their available and productive resources to civilian production.

I believe that the UN Study and the research reports on which it is based have proved that conversion is technically and economically possible. But the conversion process must be well planned in advance, i.e. before a disarmament process is initiated. As part of this preparation process it is crucial to refute the argument so often advanced when new weapon systems are debated, that military expenditures and military production create employment. To give a striking example, taken from the MX debate in the US Congress during Spring 1985, one representative is reported as saying that the full MX programme would generate on average 32,000 jobs a year over the next decade in direct employment, and as many as 95,000 if spin-offs to service industries are also included. As is so often the case, however, this is just another example of the disregard of the opportunity costs of military expenditures. How much and what kind of employment could be created by a civilian use of the same resources? One of the economists who has done some of the most extensive research on conversion, Professor Seymour Melman of Columbia University, recently pointed out that some 300,000 technicians and workers in the US and probably as many again in the USSR would lose their jobs if there were a mutual halt in the production of nuclear weapons. Hundreds of companies would also suffer substantial reductions in their revenues and profits. However, his conclusion was that these barriers to arms reduction are not immutable. Rather they reflect a failure in both countries to plan for conversion of military industries, installations and laboratories.

Many others including myself, have pointed out that if major weapon-producing countries were to publicise detailed plans for converting their armaments industries to the manufacture of other products when disarmament agreements are being negotiated, confidence in their sincerity would be greatly enhanced. Such unilateral steps would be a major confidence-building measure, improving the international atmosphere without incurring any risk. Against this background, it is a pity that more governments have not adhered to the General Assembly resolution they voted for in 1982 when approving the UN study's conclusions and recommendations, under which governments were asked to undertake national follow-up studies to look into preparation for conversion.

To the best of my knowledge, only the Swedish government has undertaken such a national follow-up study. In September 1983, the Swedish government asked me to undertake a study examining how a country like Sweden could, in the context of a broader process of disarmament in Europe, reduce its defence spending and convert resources needed for military purposes into constructive civilian use.

The main tasks given to me were as follows:

(i) to describe the nature and magnitude of Sweden's present defence efforts in economic and social terms:

(ii) to give examples of defence resources which, in the event of varying degrees of disarmament, can be converted to other purposes;

(iii) to state the feasibility of defence-sector conversion and its problems in different peace perspectives;

(iv) to state how a conversion of resources from defence to civilian use might also make a contribution to Sweden's international development cooperation with the developing countries.

My report was transmitted to the government in August 1984. There is no space to detail the findings and conclusions here. Let me only state that if there were to take place a gradual reduction of troops and weapon systems in Europe, this would allow for an equally gradual reduction of Swedish defence expenditures, making possible a process of conversion. Considering the size of the Swedish defence establishment and the Swedish defence industries within the Swedish economy, this would not cause major macroeconomic problems. But it would create certain microeconomic problems, both regionally and in human terms. These would have to be looked into very carefully, particularly at the local level, where local communities can be highly defence-dependent. Disarmament is a positive and inevitably political process, its consequences occurring as the result of 
political decisions. Thus, no single human being, and no single family need experience it as a threat to their own economic security and future.

Although the Swedish study does not necessarily establish a model for other countries, it shows that the recommendations made in the UN report can in principle be put into effect. The next question is how to convince governments that they ought to be implemented. I should not be happy to see governments. at present mostly indifferent, having to learn their lessons the hard way. Meanwhile. as is so often the case, their peoples will be the ones to suffer.

However, interest in the disarmament-development issue is increasing in many parts of the world. Conferences and seminars are organised, study groups are formed, public meetings are held. I hope this augurs well, not only for the discussion of the issue at the 40th General Assembly session, but also for the special UN Conference on Disarmament and
Development in 1986. Let it not be forgotten that governments are only likely to respond positively if they are obliged to, as a consequence of constructive political action from their own citizens.

\section{References}

Grimmet, Richard:F., 1984, Trends in Conventional Arms Transfers to the Third World by Major Supplier. 19761983. Congressional Research Service of the Library of Congress, Report No. 84-82F. Washington, May

Kende. Istvan. 1980. 'Local Wars, 1945-1976', in Asbjorn Eide and Marek Thee (eds), Problems of Contemporary' Militarism, Croom Helm, London

United Nations, 1983. Report on the World Situation

- 1985, Report on the World Social Situation

E/CN. 5/1985/2

US Census Bureau. 1985, The April 1985 US Census Bureau Report. IHT (reprinted from NUT Service), 10 April 